\title{
Basil and Jerome Compared
}

\author{
By \\ John Lewis Ewell
}




\section{BASIL AND JEROME COMPARED}

By John Lewis Ewell, Professor of Church History, HOWARD UNIVERSITY

(Read Dec. 28, 1900)'

$\mathrm{B}^{\text {ASIL was born about } 329 \text { A.D., and died } 379 \text { A.D. Jerome }}$ was born about 340 and died 420 . So Basil was Jerome's senior by some eleven years, while Jerome outlived Basil over forty years.

A recent reading of both Basil and Jerome has impressed me vividly with the contrast between the two Fathers at one point, and on reflection I have thought that possibly in respect to a number of traits it might be interesting to put them side by side. If the contrast is not in all respects a sharp one, the lover of Plutarch will recall that in some cases the same is true of his heroes.

Their most striking divergence was as to celibacy, not but that both were celibates, indeed they were both ascetics in general, of the most relentless kind, addicted to a vegetable diet, scanty and ragged clothing, insufficient and interrupted sleep on the bare ground, only indulging in a bath in case of severe illness and conspicuous for "unwashedness." Alas, for the world, Basil outstripped Jerome in asceticism so that while the latter lived to be fourscore, Basil, the brightest star of the Cappadocian firmament, vanished at fifty, and he was even then an old man, burdened and broken with manifold diseases. But when it came to celibacy, Jerome let his ascetic principles run away with him. His great aim and de- 
light and warfare even was to promote the unmarried state, and to obliterate [82] every impulse in the opposite direction. Of course, he tolerated marriage. It was necessary in order to save the race from extinction; he even claimed to honor marriage; it was, he said, that part of the Lord's field which yielded thirty-fold, although the chief gain which he expected from marriage was virgins-that is, those who should be devoted by their parents to the celibate life, but what he emphasized was the sixty-fold of unbroken widowhood and the hundred-fold of life-long celibacy. This was the angelic life on earth. It filled his heart with joy if a little girl of ten were consecrated by her parents to the virgin life. When the fair and high-born Blesilla was left a widow at twenty, he devoted himself to fortifying her resolution not to remarry, and to fostering in the gentle, intellectual, and spiritually minded young lady ascetic practices to the most cruel degree. Hers is a tragic instance of severity to the body. When eight months later she was borne to the grave with all the pomp of a Roman patrician funeral, a great outcry arose against the monks, and particularly against Jerome as the cause of her untimely death, and the demand was-Away with the monks, stone them, hurl them into the Tiber-so that Jerome withdrew from Rome through fear of the vengeance of the mob. If he wrote to a widow, it was to adjure her against a second marriage. He rejoiced when married people resolved to live as though they were unmarried, and if, after such a vow they resumed the conjugal relation and, as happened in one instance, the wife did penance for her supposed sin by a pilgrimage to Palestine, he applauded her and did his utmost to induce her husband to lay upon himself a like punishment. His letters, and that when writing to women, are so full of denunciations of all sexual impulses and they go into so minute details that it would seem as though they must have stimulated the very thing which they denounced with such vehemence and iteration.

When you pass from the writings of Jerome to those of 
Basil, you breathe a different atmosphere. He agreed with Jerome in his interpretation of the thirty- and sixty- and hundred-fold and in regarding the celibate as the angelic life, but he does not permit a girl to take the vow of virginity [83] until she knows what she is doing-that is, has reached at least sixteen or seventeen years. When he writes to widows it is to comfort them with the thought of the noble character of their deceased husbands, or of the divine love and wisdom that will make their bereavement a blessing, with never a word of warning against a remarriage, and in all his writings there is a refreshing absence of that minute and morbid and indelicate detail which is so prominent and offensive in Jerome.

Jerome was notoriously a violent saint. Did Jovinian venture the assertion that pure married life was as holy as celibacy?-his writings were but, "the hissings of the old serpent." Vigilantius advocated views similar to those of Jovinian, therefore his books were "vomited forth in a drunken fit." A Roman Catholic friend who is now a bishop in that Church, once remarked to me that literature can show nothing more vituperative than Jerome's denunciations of Vigilantius. He likens Ambrose to the croaking raven and to the ungainly jackdaw. Pelagius offered no point of attack in his character so he is described as "a stupid fool laboring under his load of Scotch porridge"-a criticism that would have pleased Dr. Johnson. When his bosom friend Rufinus, ventured to differ from him he became "a grunter." Jerome's bitter pen did not spare the dead. He termed Rufinus after his death "the scorpion." It would seem that Ruskin could not have read Jerome extensively, else he would not extol his "sweetness of character." : Basil, while not altogether superior to the prevalent violence in language, was far more courteous than his times.

In theology, Jerome had no mind of his own. He was most of all consistent in his unwavering determination to be

× Our Fathers have told us.-Chap. iii., "The Lion-Tamer." 
orthodox, whatever that might mean to the Church. He writes to Bishop Damasus of Rome, that he has hitherto maintained but one hypostasis in the Trinity, but if he, Damasus, decrees that there are three, he will not hesitate to speak of three. Basil, on the contrary, is preeminently a leader and originator in theology. His work on the Holy Spirit was the worthy successor and supplement of the writings of Athanasius on the Deity of the Son.

[84] Basil had an altogether broader and richer and more winsome nature than Jerome. Jerome was not absolutely without humor. He commends Eustochium, who had consecrated her wealth and rank and beauty to a life of perpetual virginity by contrasting her with some "rough, unsightly countrified fright, who most likely never married because she could not find a husband," - an outline sketch suggesting Burns's line, "Ye 're aiblins nae temptation." But playful sallies are hard to find in Jerome.

Basil, on the contrary, often permits the bright thread of humor to light up his serious thought. If he is persecuted by an unlettered tool of the emperor who bears the name of the prince of Greek orators, he terms him an illiterate Demosthenes. If the imperial minister threatens to torture him unless he will submit, he replies: "If you will cut out my liver you will do me a great kindness, for it has always been a trouble to me where it is." He begs the workingmen in his audience to be patient with his long sermon, for he says, the longer I preach, the longer you will be kept from dice and similar evils. He writes to a man who has regained his appetite by eating pickled cabbage, that for the future he shall think nothing is equal to that dish. Basil took delight in the beautiful landscape of his picturesque Cappadocia, in the grandeur of the starry heavens, and in the variety and mystery and mutual adaptability of plants. His Hexameron, or Discourses on the Six Days of Creation, abounds in beautiful passages which illustrate his appreciation of the book of nature. 
Jerome and Basil were both familiar with the classics, although Basil's five years in Athens gave a polish to his education which Jerome never attained. Jerome's famous dream made him abjure the classics, but he could not keep his vow, for his writings to his latest years abound in classical allusions. Basil's appreciation of the classics suffered no such shock. He always delighted in them, and, if the correspondence attributed to them be, as is commonly supposed, genuine, continued in familiar relations with the great heathen humanist Libanius and sought out pupils for him, whom Libanius gladly taught, if necessary, for nothing.

[85] Basil was a democrat. While he bore himself with dignity, possibly not without a touch of pride, because of his high birth, rare education, rigorous asceticism, and exalted position as Archbishop of Cappadocia, he affirmed that all men are by nature deserving of equal honor. He ridicules abstinence from swine's flesh, because every creature of God is good and to be received with thanksgiving. He bids his hearers sail the voyage of life by the constellations of the commandments of God. Passages striking for their vigorous and beautiful thought and liberal spirit are far more frequent in Basil than in Jerome.

Jerome far surpasses Basil in pictures of his time. His long residence in Rome and probably a natural aptness for vivid narrative, account for this. To him we owe the most lifelike descriptions that have come down to us of the luxury and profligacy of the later empire, of its women with painted cheeks and eyebrows, towering headgear, and girdles so tight as nearly to cut them in two, and of their perfumed and mincing beaux, of the intoxication that made their banquets disgusting, and of the immorality that found its way even into the ranks of priests and nuns. It is he above all others who has given us our most graphic and lurid pictures of the sack of Rome in 4IO with its carnival of pillage, lust, and murder, and the agony that spread to all the shores of the Mediterranean, and even filled the religious homes of distant 
Bethlehem, where Jerome dwelt, with throngs of ragged, starving, and wounded fugitives.

Both lives afford an illustrious exhibition of courage whose memory shall never die. Basil resisted the Arian emperor, Valens, at peril of torture, confiscation, and banishment, and the bishop overawed the emperor. When Valens entered Basil's church there was something in its spiritual atmosphere, its throng of devout worshippers, its mighty waves of sacred song, and above all in that majestic figure of the presiding archbishop, the wasted and worn ascetic, yet the eloquent preacher in whose countenance there was something of almost more than human purity and dignity and sympathy that overmastered the imperial haughtiness, and Valens held a private [86] interview with Basil in a retired room of the cathedral and left a gift for the archbishop's asylums which were on so vast a scale as to be designated "the new city." The reconciliation of the emperor was, however, as momentary as that of Saul to the outlawed David. Basil became an exile, and the congregation of his diocese, because they had caught his inflexible adherence to the Athanasian faith, were turned out of their churches and compelled to worship God in the open air in the rigors of winter amid the Cappadocian mountains.

Jerome showed at once his indomitable courage and his breadth of view as a translator of the Bible. This work of his presents at once his great monument and the noblest aspect of his character. The current versions were corrupt and conflicting, but they were intrenched in the affection and respect of many generations. To change them seemed to the popular mind little short of sacrilege. Because Jerome did this, he brought down on himself the bitterest denunciations, and congregations were rent into parties for and against the change. In at least one instance, which is probably typical of many, a bishop almost lost his position for presuming to quote one of Jerome's new renderings. In all this Jerome was condemned as the troubler of Israel, but none of these 


\section{Basil and Jerome Compared}

things moved him. He repaid vituperation in kind with interest,-for meekness was never his specialty,-and labored on with the sympathy of the more enlightened, and with generous gifts even from distant Spain to defray the wages of copyists. He did not hesitate to call in the help of Jewish rabbis in deciphering the Hebrew. He believed that he had the mighty aid of the prayers of the apostle Paul. The cave in Bethlehem, where he wrote, became to him a second Paradise, and his labor upon the sacred text so sweet as to afford him a foretaste of heaven. First he revised the Septuagint and then made a new translation of the whole Bible from the original, giving to the latter work eleven golden years, beginning it in 392 and finishing in 404, and subsequently, as old age, with poverty, bereavement, and infirmities, particularly failing sight, which made it difficult to distinguish Hebrew letters, settled down upon him, it was his delight to expound the text which he had corrected, while $[87]$ he exulted that the Jews could no longer reproach the church for its corrupt readings, and looked away from the denunciations of his contemporaries to the gratitude of coming generations, with an assurance which time has amply justified. Martin Luther, himself a prince among translators of the Bible, while he recoiled with violent condemnation from Jerome's asceticism, affirmed that as a translator he excelled all others.

If Jerome, as a recent biographer ${ }^{x}$ has said, lived and reigned tooo years in the principles and usages of the medieval church, Basil has a sure place in the gratitude of all generations of those who adore the deity of the Holy Spirit, and both Jerome and Basil deserve canonization not only in the Roman Catholic Church, but in the Church Catholic, in the broadest meaning of the term.

× W. H. Freemantle, Prolegomena to Jerome, Nicene and Post-Nicene Fathers, vol. vi. 